\title{
The Short- and Long-Term Effects of Financial Sector Development on Economic Growth in Saudi Arabia: An ARDL Model Analysis
}

\author{
Abdulaziz Adel Abdulaziz Aldaarmi ${ }^{1}$ \\ ${ }^{1}$ Faculty of Business Administration, University of Tabuk, KSA \\ Correspondence: Abdulaziz Adel Abdulaziz Aldaarmi, Faculty of Business Administration, University of Tabuk, \\ KSA. E-mail: aaldaarmi@ut.edu.sa
}

Received: June 2, 2021

doi:10.5539/ijef.v13n9p25
Accepted: July 26, 2021

Online Published: July 30, 2021

\begin{abstract}
The goal of this research was to explore Financial Development and Economic Growth in Saudi Arabia. This would provide evidence pertaining to the relationship between financial sector development and economic growth within the country's context. In regard to methodology, this study purposed an Autoregressive Distributed Lag (ARDL) model and an ECM model to underline the short and long-term dynamics. To measure financial development, this study implemented the value of credits provided by the financial sector to the private sector divided by GDP. Furthermore, based on a comprehensive and holistic reading of the literature, this study also implemented the control variables of trade openness, gross fixed capital formation, and the labor force. The findings show that there are long- and short-term relationships between financial development and economic growth. The regression coefficients for the ARDL model and Unrestricted Error Correction Model (ECM) were found to be statistically significant at the $10 \%$ level. All control variables were found to influence the relationship between the independent and dependent variables.
\end{abstract}

Keywords: financial development, economic growth, Autoregressive Distributed Lag (ARDL) model

\section{Introduction}

It is accepted that countries with well-defined and operating financial systems are going to show immense progress in their economic growth (Beck, 2006). There is however no scientific unanimity on the relationship between financial development and economic growth, which is part of the ongoing debate on the finance growth-nexus conundrum at both the theoretical and empirical levels. The history of this concern is divided along the lines of two schools of thought.

The proponents of the first such school of thought held that economic growth is untenable without the presence of proper financial development (Nasir et al., 2019). More specifically, they argued that financial development explicitly affects economic growth by influencing the allocated or allowed divestments towards technological innovation, investment, and savings (Beck, 2006). Several studies have concurred with this assessment of positive economic growth based on financial sector development. The proponents of the second school of thought, however, challenged this notion by proclaiming that finance did not have any relevant effect on the degree of economic growth that a nation is capable of expressing (Neave, 2017). They were referred to as neoclassical theorists and argued that the relationship between economic growth and financial development had been overemphasized in the relevant literature (Christopoulos, 2004). Other relevant studies emphasized this disconnect between the two variables by providing arguments for an inverse association between them (Ductor, 2015).

Financial development stimulates economic growth by raising capital accumulation rates (Bist, 2018). These are defined as the rates at which growth in wealth is realized through profits or investments. Four propositions that could advance this notion were also listed by the author, who stated that financial systems foster productivity improvements by;

- Selecting the projects and entrepreneurs that are more likely to succeed.

- $\quad$ Ensuring that the entrepreneurs have access to external sources of financing.

- Ensuring the availability of appropriate investment vehicles suited to enable the diversification of the inherent risk attached to innovative undertakings. 
- Ensuring that the greatest profit is realized from undertaking uncertain innovative business ventures.

\subsection{Research Problem}

A concurrent study also concluded that financial intercessors directly exert a positive influence on the total productivity growth experienced, which directly gets passed on to overall GDP growth. It argued that this economic growth is due to factors internal to the economy, as opposed to external ones; hence the financial intercessors that directly affect growth through their influence on savings. However, other studies, such as Nawaz et al. (2019), found no evidence to back up the claim that economic improvements boost growth by raising overall savings and investment.

Čižo et al. (2020) aimed to advance this view by positing that the contribution of financial development to economic growth is inherently dependent on the economic backwardness of an economy, which is measured by considering how unevolved an economy is at the outset of an economic development. The author hence posited that the further an economy is underdeveloped at the outset, the easier it will be to quantify and assess the economic growth it will have experienced by the end. This study was aimed at critically examine and assess the relationship between financial development and economic growth in Saudi Arabia by using an Autoregressive Distributed Lag (ARDL) Model, which is suited to predict the future values of a variable based on its past ones. It is a dynamic model in which the effect of a regressor $\mathrm{x}$ on $\mathrm{y}$ occurs over a considerable length of time, rather than all at once. Saudi Arabia is considered an interesting context to investigate because it is one of the few countries to have a primarily resource-dominated economy, which is predominantly driven by the revenues associated with being one of the largest petroleum exporters in the world. The country - the economy of which, however, comprises oil and non-oil sector-is however taking steps to try and ensure that it is capable of decreasing its reliance on oil exports and of diversifying its economic resources. This study was aimed to add to the existing literature on this topic by assessing how financial development and economic growth are related in resource-dominated economies, with Saudi Arabia as a case example.

\subsection{Research Objectives}

This study was interested in quantifying the relationship between financial development and economic growth in Saudi Arabia using an ARDL model. The aim of this paper is hence to:

1) Assess the dynamics of the short- and long-term relationships between the financial development and economic growth of Saudi Arabia.

2) Assess the effects of trade openness on the relationship between economic growth and financial development.

3) Investigate the extent to which the labor force affects the relationship between financial development and economic growth.

4) Examine the effect of gross fixed capital formation on financial development and how this translates to economic growth.

\subsection{Significance of the Study}

This study finds significance in the various players and entities with a stake in measuring or assessing the economic growth experienced by a country. Given the current lack of relevant information on assessments made about the economy of Saudi Arabia, this study was aimed at filling this gap by proposing an empirically tempered assessment of the nature of the dichotomy between financial development and economic growth in Saudi Arabia. Its findings are useful to regulators, economists and researchers as they highlight the inherent benefits or deficits that a resource-driven economy experiences in the fiscal performance its economy registers due to relevant action in its financial development.

\section{Literature Review}

Conversations on the notion of a finance-growth nexus have been held since Goldsmith (1969) advanced the idea that development in the financial sector is necessary for economic growth by positing, at an empirical level, the notion that there is a positive relationship between financial development and GDP per capita.

This paper considered the empirical relationship between long-term growth and financial development represented in proxy by the ratio between bank credit to the private sector and GDP. Although this proxy was found to be positively associated to economic growth in a large cross-country sample, this impact was found to change across countries and to be even negative in a panel data for Latin America. The paper further argued that the core channel of transmission from financial development to economic growth is the efficiency attached to an investment, and not its volume. This conversation has become more specific and confined to particular locations 
and nations in order to analyze the results of this endeavor at a realistic empirical and theoretical level (Ibrahim \& Alagidede, 2018; Yang, 2019).

Both perspectives have experienced relevant strides in their definition in the literature because of important tests having been performed to assess this topic. To make its assessments, this study utilized error correction and variance decomposition techniques, including long run structural modelling. In its application, it should include the clear identification and over-identification of any restrictions on the cointegrating vector, which would take care of a major concern associated with the approach. To the best of our knowledge, no other studies have incorporated the use of Least Square Regression Modelling (LSRM). The study also vigorously tested the stability of its functions according to the Chow and Cumulative Sum (CUSUM) tests. The findings of this study revealed that the direction of causation between these two variables for Saudi Arabia is supply-leading rather than demand-following, which essentially equates it to financially development driven model for economic growth (Masih, 2009).

An empirical study was conducted to assess the effects of financial development on the oil and non-oil sectors of the Saudi economy. It utilized the ARDL Bounds tests technique and revealed that financial development has a positive impact on the growth of the non-oil sector. The impact on its oil counterpart and on total GDP growth, however, was found to be either negative or not significant, thus bringing about the notion that the relationship between financial development and economic growth may inherently differ in resource-dominated economies (Samargandi, 2014).

The financial sector has experienced some improved performance that could also be attributed to its processes of financial intermediation between savers and investors and between lenders and borrowers, as well as to the redistribution of the funds available for investments, which has led to the achievement of widely anticipated stable economic growth. As an empirical study, it was aimed at assessing the relationship between inflation and the financial sector developments in Saudi Arabia for the 1982-2013 period. To do so, it utilized an autoregressive distributed lag bound testing approach suited to examine the existence of a long-term relationship between the inflation rate and financial sector development. This approach was deemed advantageous in that it is applicable irrespective of whether the underlying variables are purely I( 0$)$, purely I(1) or mutually co-integrated. It accordingly concluded that inflation and trade liberalization policies are the main obstacles to optimal financial performance (Almalki, 2015).

\section{Empirical Methodology}

The purpose of this research was to provide evidence in regard to the association between financial sector development and economic growth in Saudi Arabia. In order to capture the short- and long-term dynamics, this study used an ARDL model. To measure financial development, we utilized the value of the credit given by the financial sector to the private sector divided by the GDP. Furthermore, based on a thorough examination of the literature, this study included gross fixed capital formation, trade openness, and the labor force as control variables. Accordingly, the ARDL method was used in two stages. In the first, co-integration was tested in the framework of the unrestricted error correction (UECM) model. The second stage included the estimation of the long-term equation, and then the construction of an Error Correction Model (ECM).

Based on economic theory and on the models applied in previous studies on the same subject, the following equation was estimated for the purpose of measuring the impact of the development of the financial sector on the economic growth of Arabia Saudi during the 1990-2018 period.

Therefore, the linear model specification could be presented as:

$$
G D P_{t}=\alpha_{0}+\alpha_{1} C P S_{t}+\alpha_{2} G F C F_{t}+\alpha_{3} T R_{t}+\alpha_{4} L F_{t}+\mu_{t}
$$

Where, $i$ and $t$ are representative of country and time, respectively, and GDP is the economic growth defined as the log of the real gross domestic product (GDP). Credit to the private sector (CPS) is a proxy for financial sector development and is measured as the ratio of GDP. GFCF is the ratio of gross fixed capital formation over GDP. TR represents trade openness and is defined as the ratio of imports plus exports to GDP. LF is the labor force. $\alpha_{0}$ is a constant and $\alpha_{1}, \alpha_{2}, \alpha_{3}$, and $\alpha_{4}$ are the coefficients of private credit, gross fixed capital formation, trade openness, and labor force, respectively. $\mu \mathrm{t}$ is the error term.

To evaluate the presence of a long-term relationship Pesaran (2001) developed a limits test based on Wald or F-statistics. Under the null hypothesis of a no cointegration relationship between the studied variables, the asymptotic distribution of the F statistics is non-standard, regardless of whether the explanatory variables are purely descriptive $\mathrm{I}(0)$ or $\mathrm{I}(1)$.

The cointegration relationship between economic growth and the development of the financial sector was 
estimated by ARDL using the bounds test, which is based on the following Unrestricted Error Correction Model (UECM):

$$
\begin{gathered}
\Delta G D P_{t}=\beta_{0}+\sum_{i=1}^{p} \beta_{1} \Delta G D P_{t-i}+\sum_{i=0}^{p} \beta_{2} \Delta C P S_{t-i}+\sum_{i=0}^{p} \beta_{3} \Delta G F C F_{t-i}+\sum_{i=0}^{p} \beta_{4} \Delta T R_{t-i}++\sum_{i=0}^{p} \beta_{5} \Delta L F_{t-i}+ \\
\beta_{6} \mathrm{CPS}_{\mathrm{t}-1}+\beta_{7} \mathrm{GFC}_{\mathrm{t}-1}+\beta_{8} \mathrm{TR}_{\mathrm{t}}+\beta_{9} \mathrm{INF}_{\mathrm{t}-1}+\beta_{10} \mathrm{LF}_{\mathrm{t}-1}+\varepsilon_{t}
\end{gathered}
$$

The null hypothesis was tested by considering the unrestricted ECM for economic growth in equation (2) excluding all variables; more formally, we performed a joint significance test, where the null and alternative hypotheses were:

$\mathrm{H} 0: \quad \beta 6=\beta 7=\beta 8=\beta 9=\beta 10=0$

$\mathrm{H} 1: \beta 6 \neq \beta 7 \neq \beta 8 \neq \beta 9 \neq \beta 10 \neq 0$

The long-term ARDL(q1,q2,q3,q4,q5, q6) equilibrium relation was given as:

$$
\Delta G D P_{t}=a_{0}+\sum_{i=1}^{q 1} a_{1} G D P_{t-i}+\sum_{i=0}^{q 2} a_{2} C P S_{t-i}+\sum_{i=0}^{q 3} a_{3} G F C_{t-i}+\sum_{i=0}^{q 4} a_{4} T R_{t-i}+\sum_{i=0}^{q 5} a_{5} L F_{t-i}+\vartheta_{t}
$$

Where $\vartheta_{t}$, defined as the term error, is used more frequently between the GDP and its equilibrium level, which is to be filled in the next period.

The Short-term ARDL equilibrium relation was thus given as:

$$
\begin{gathered}
\Delta L G D P_{t}=c_{0}+\sum_{i=1}^{p} c_{1} \Delta L G D P_{t-i}+\sum_{i=0}^{p} c_{2} \Delta C P S_{t-i}+\sum_{i=0}^{p} c_{3} \Delta G F C_{t-i}+\sum_{i=0}^{p} c_{4} \Delta O P E_{t-i}+ \\
\sum_{i=0}^{p} c_{5} \Delta L F_{t-i}+\rho_{t}
\end{gathered}
$$

\section{Empirical Results}

\subsection{Unit Root Test Results}

Before evaluating the right framework for the econometric model, it was necessary to analyze the univariate aspects of all data series and establish the degree to which they were integrated. The augmented Dickey-Fuller (ADF) test was employed for that purpose and the results are summarized in Tables 1. Testing for stationarity (refer to Table 1) showed that all our variables were integrated of order 1 [I(1) and thus stationary in difference].

Table 1. Results of unit root tests

\begin{tabular}{lcccc}
\hline & \multicolumn{2}{c}{ Level } & \multicolumn{2}{c}{ First difference } \\
\hline CPS & {$[t-b a r]$} & $p-$ value & {$[t-$ bar $]$} & $p$ value \\
GFCF & -0.963 & 0.752 & -4.465 & 0.001 \\
LF & -2.096 & 0.247 & -4.035 & 0.004 \\
GDP & -1.731 & 0.405 & -4.966 & 0.000 \\
OP & -0.390 & 0.897 & -5.467 & 0.000 \\
\hline
\end{tabular}

Note. ${ }^{*}{ }^{*} *{ }^{*} * * *$ represent significance at the $10 \%, 5 \%$ and $1 \%$ levels, respectively.

\subsection{The ARDL Cointegration Test}

To test the existence of a long-term relationship (cointegration), we used advanced testing and estimate procedures (Pesaran \& Shin, 1999).

The bounds test results are shown in Tables 2 and 3. As there were four regressors in the model, $K=4$. At the 5\% level of significance, the F-statistics were found to be 5.67 and to exceed the upper bound of the critical value band. We thus rejected the null hypothesis of no long-term relationship between the variables. The test results thus suggest the existence of such long-term relationship.

Table 2. Bounds test

\begin{tabular}{lcccc}
\hline Equation & Wald F-Statistic & Lower Bound I0 & Upper Bound I1 & Outcome \\
\hline GDP & 5.67 & 3.23 & 4.35 & Cointegrated \\
\hline
\end{tabular}

Source: Author's calculations.

Table 3. Critical value bounds

\begin{tabular}{lccc}
\hline & Significance & Lower Bound I0 & Upper Bound I1 \\
\hline $\mathbf{1 0 \%}$ & 2.72 & 3.77 \\
$\mathbf{5 \%}$ & 3.23 & 4.35 \\
$\mathbf{1 \%}$ & 4.29 & 5.61 \\
\hline
\end{tabular}


Given that our specification was cointegrated, the next stage of the procedure involved the estimation of the coefficients of the long-term relations and the associated error correction model (ECM) using the ARDL approach. The order of the distributed lag on the dependent variable was selected by means of the Schwartz Bayesian Criterion (SBC) and was found to be 1 . The SBC criteria were used to select the ARDL $(1,0,3,0)$. The long-run estimated coefficients are shown in the Table 4.

The variables were found to explain about $98 \%$ of the change in economic growth-the value of the coefficient of determination was found to be equal to 0.98 and the variable financial development was found to have a positive and significant effect on the growth rate of the output at a 5\% significance level In fact, a $1 \%$ increase in the credit to private sector/GDP ratio (CPS) was found to be associated to a $0.4 \%$ increase in output level. As expected for the case of Saudi Arabia, investment levels and the labor force were found to be the main ingredients for economic development. However, trade openness was reported as not statistically significant. The investment variable was found to have a significant effect on the growth rate of the output at a $5 \%$ significance level; its coefficient was found to be equal to 0.004 , which means that an increase of $1 \%$ in the trade openness/GDP ratio would result in $0,4 \%$ increase in the rate of growth of the output. The labor force variable was found to have a significant positive effect on the growth rate of the output at a 5\% significance level, its coefficient being equal to 3.27 , which means that an $1 \%$ increase in the labor force would correspond to a $3.27 \%$ increase in the rate of growth of the output. In contrast, trade openness was reported to have a negative effect on economic growth. We concluded that, in the long term, financial development leads to economic growth.

Table 4. The ARDL long-term model

\begin{tabular}{cccc}
\hline Variables & Coefficient & t-Statistic & Probability Value \\
\hline CPS & $0.004^{* *}$ & 2.750 & 0.013 \\
TR & $-0.003^{*}$ & -1.900 & 0.073 \\
FBC & $0.004^{* *}$ & 2.750 & 0.013 \\
LF & $3.272^{* *}$ & 0.795 & 0.029 \\
\hline
\end{tabular}

Note. ${ }^{*} * * * * * *$ represent significance at the $10 \%, 5 \%$, and $1 \%$ levels, respectively.

\subsection{Estimation of the ARDL Error Correction Model}

After analyzing the long-term relationship according to the co-integration model, the ECM model was estimated to test the short-term relationship between the independent and the dependent variables.

Table 5 presents the short-term ARDL model. It is worth noting that the error correction coefficient was found to be significant and to take a negative value of 0.11 , indicating the speed of return to the long-term equilibrium. This means that any deviation from the long-term equilibrium path between the explanatory variables and the independent variable in period t-1 will be partially compensated in period t. Moreover, the result reveals that, in the short-term, the variables have the same signs as in the long-term. The impact of financial development on the output of Saudi Arabia is positive and significant. The coefficients for the other explanatory variables are well-behaved and have the expected sign and significance.

We can thus conclude that, both in the short- and the long-term, there is a positive relationship between financial development and economic growth.

Table 5. Error Correction Model (ECM)

\begin{tabular}{cccc}
\hline Variables & Coefficient & t-Statistic & Probability Value \\
\hline$\Delta \mathbf{R G D P}_{\mathbf{t}-\mathbf{1}}$ & $0.889^{* * *}$ & 10.060 & 0.000 \\
$\Delta \mathbf{C P S}_{\mathbf{t}-\mathbf{1}}$ & $0.189^{* * *}$ & 4.329 & 0.008 \\
$\Delta \mathbf{T R}_{\mathbf{t}-\mathbf{1}}$ & $-0.013^{* *}$ & -2.295 & 0.021 \\
$\Delta \mathbf{F B C}_{\mathbf{t}-\mathbf{1}}$ & $0.706^{*}$ & 3.181 & 0.053 \\
$\Delta \mathbf{L F}_{\mathbf{t}-\mathbf{1}}$ & $0.456^{* * *}$ & 2.865 & 0.007 \\
$\mathbf{E C T}_{\mathbf{t}-\mathbf{1}}$ & $-0.110^{* * *}$ & -5.839 & 0.000 \\
\hline
\end{tabular}

Note. *** significance at the $1 \%$ level.

\section{Discussion}

Using the ADF test, which was applied to all of the independent variables, we did not find enough evidence to reject the null hypothesis that there is a unit root at the $1 \%$ significance level. The variables were found to be of 
order 1 and, based on the ARDL model, our study concluded that financial development and economic growth have a long-term link. This is in line with the findings of Marashdeh and Al-Malkawi (2014), who examined the relationship between financial deepening and economic growth and uncovered a statistically significant positive long-run link. Marashdeh and Al-Malkawi (2014), on the other hand, failed to identify a statistic for the short-term relationship. Mohieldin et al. (2019) found associations similar to those of our study in regard to the variables of real growth per capita, labor force, and trade openness, whereby a positive relationship was found in regard to financial development. The findings of our study provide strong support for the association between economic growth and financial development in both the long- and short-term. The regression coefficients for both the ARDL model and ECM were found to be statistically significant at the $10 \%$ level. In the context of the Middle East and North Africa (MENA) region, Samargandi et al. (2014) investigated the relationship between financial development and economic growth in addition to how the former is affected by the institutional conditions found in the Kingdom. They found a negative but not statistically significant relationship between the two. They did however find that the country's institutional environment is crucial for the financial sector and that a move away from an oil-based economy will help further improve the quality of financial institutions.

It is responsible for enhancing productivity and competition in the economy, which will be to the full advantage of the citizens. Samargandi et al. (2014) demonstrated that the financial markets are important enablers of the private sector, as such sector will always seek to improve its financing options and, consequently, government credit plays a huge role in addition to the government's ability to facilitate trade openness This is especially takes place in countries with strong contract enforcement (Guo \& Luo, 2017). The Kingdom of Saudi Arabia has done a good job in regard to the provision of credit to the private sector, which, based on our findings, has shown a positive relationship with financial development. However, in relation to trade openness, our study has shown that the Kingdom still needs to improve a number of aspects in order to ensure that the financing options available to the private sector are adequate to bolster the efforts made toward increasing the volume of the GDP, which will potentially lead to a level of financial development in line with the country's Vision 2030 plan.

This is then what contributes to a developed labor force in the Kingdom and, according to the World Bank (2021), there has even been an increase in the labor force participation of the female population aged 15 and above, which has increased by $64 \%$ over the span of two years. The government further requires those organizations with more than 50 employees to provide them with a training program on an annual basis. Such training should take into consideration the costs associated, which should be covered by the organizations themselves (Samargandi et al., 2015). The government has also made it compulsory for employers to draft policies suited to serve as internal regulations. The law is however unclear on whether the Ministry of Labor needs to approve these internal regulations.

According to Thach (2021), Endogenous growth theory suggests that openness to international trade will improve the quality of economic growth through the acceleration and improvement of the factors of productivity; our findings, however, seem to empirically suggest that the opposite is true for Saudi Arabia. An explanation for this may hinge on the fact that the production capacity of the non-oil sectors is not very competitive, given the predominantly oil-based economy of the Kingdom.

\section{Conclusion and Recommendation}

\subsection{Conclusion}

Our findings can be attributed to the policies implemented by the Saudi government in order to foster development in the country by means of legislation aimed at encouraging the provision of cheap credit to the private sector; this enhances company growth and further translates into employment for the population. The private sector is capable of boosting the volume of GDP in any country as it not only increases economic diversification, but also generates employment.

\subsection{Recommendations}

The findings of our study yield the following recommendations:

I. The government should devise more policies aimed at importing technological and intermediate products in order to lead to greater economic diversification, which will promote not oil-based output/exports from the Kingdom. This will promote an increase in the trade openness of Saudi Arabia and help the government in achieving its Vision 2030 plan.

II. The government should continue in its support of the private sector, as this will influence the savings and investment decisions in the Kingdom and reduce intertemporal risk. To ensure sustainable growth, however, 
any credit to the private sector should ensure that there is a good transmission mechanism to those segments of the financial market that are linked to such sector.

III. In consideration of the country's demographic changes in addition to the fall of oil prices, Saudi Arabia's government should formulate new development models aimed at fostering increased labor productivity. The population is growing rapidly, and the kingdom will need to develop policies that will enable it to be absorbed into the workforce while taking into account its demographical needs and living standards.

\section{References}

Akcigit, U., \& Nicholas, T. (2019). History, microdata, and endogenous growth. Annual Review of Economics, 11, 615-633. https://doi.org/10.1146/annurev-economics-080218-030204

Almalki, A. M., \& Batayneh, K. I. (2015). The relationship between inflation and financial development in Saudi Arabia. The Journal of Developing Areas, 49(6), 321-332. 10.1353/jda.2015.0088

Beck, T., \& Demirguc-Kunt, A. (2006). Small and medium-size enterprises: Access to finance as a growth constraint. Journal of Banking \& Finance, 30(11), 2931-2943. https://doi.org/10.1016/j.jbankfin.2006.05.009

Bist, J. P. (2018). Financial development and economic growth: Evidence from a panel of 16 African and non-African low-income countries. Cogent Economics \& Finance, 6(1), 1449780. https://doi.org/10.1080/23322039.2018.1449780

Christopoulos, D. K., \& Tsionas, E. G. (2004). Financial development and economic growth: Evidence from panel unit root and cointegration tests. Journal of Development Economics, 73(1), 55-74. https://doi.org/10.1016/j.jdeveco.2003.03.002

Čižo, E., Lavrinenko, O., \& Ignatjeva, S. (2020). Analysis of the relationship between financial development and economic growth in the EU countries. Insights into Regional Development, 2(3), 645-660. https://doi.org/10.9770/ird.2020.2.3(3)

Ductor, L., \& Grechyna, D. (2015). Financial development, real sector, and economic growth. International Review of Economics \& Finance, 37, 393-405. https://doi.org/10.1016/j.iref.2015.01.001

Goldsmith, R. W. (1969). Financial structure and development (No. HG174 G57).

Guo, Z. Y., \& Luo, Y. (2017). Credit constraint exports in countries with different degrees of contract enforcement. Business and Economic Research, 7(1), 227-241. https://doi.org/10.5296/ber.v7i1.10923

Haque, M. I. (2020). The Growth of Private Sector and Financial Development in Saudi Arabia. Economies, 8(2), 39. https://doi.org/10.3390/economies8020039

Ibrahim, M., \& Alagidede, P. (2018). Effect of financial development on economic growth in sub-Saharan Africa. Journal of Policy Modeling, 40(6), 1104-1125. https://doi.org/10.1016/j.jpolmod.2018.08.001

Marashdeh, H. A., \& Al-Malkawi, H. A. N. (2014). Financial deepening and economic growth in Saudi Arabia. Journal of Emerging Market Finance, 13(2), 139-154. https://doi.org/10.1177/0972652714541339

Masih, M., Al-Elg, A., \& Madani, H. (2009). Causality between financial development and economic growth: an application of vector error correction and variance decomposition methods to Saudi Arabia. Applied Economics, 41(13), 1691-1699. https://doi.org/10.1080/00036840701320233

Mohieldin, M., Hussein, K., \& Rostom, A. (2019). On financial development and economic growth in the Arab Republic of Egypt. The World Bank. https://doi.org/10.1596/1813-9450-9008

Nasir, M. A., Huynh, T. L. D., \& Tram, H. T. X. (2019). Role of financial development, economic growth \& foreign direct investment in driving climate change: A case of emerging ASEAN. Journal of Environmental Management, 242, 131-141. https://doi.org/10.1016/j.jenvman.2019.03.112

Nawaz, K., Lahiani, A., \& Roubaud, D. (2019). Natural resources as blessings and finance-growth nexus: A bootstrap ARDL approach in an emerging economy. Resources Policy, 60, 277-287. https://doi.org/10.1016/j.resourpol.2019.01.007

Neave, E. H. (2017). The economic organisation of a financial system. Routledge. https://doi.org/10.4324/9780203702758

Samargandi, N., Fidrmuc, J., \& Ghosh, S. (2014). Financial development and economic growth in an oil-rich economy: The case of Saudi Arabia. Economic modelling, 43, 267-278. https://doi.org/10.1016/j.econmod.2014.07.042 
Thach, N. (2021). How have NESTs grown? Explanations based on endogenous growth theory. Cogent Economics \& Finance, 9(1). https://doi.org/10.1080/23322039.2021.1913847

World Bank. (2021). Retrieved from https://data.worldbank.org/indicator/SL.TLF.CACT.FE.ZS?locations=SA

Yang, F. (2019). The impact of financial development on economic growth in middle-income countries. Journal of International Financial Markets, Institutions and Money, 59, 74-89. https://doi.org/10.1016/j.intfin.2018.11.008

\section{Copyrights}

Copyright for this article is retained by the author(s), with first publication rights granted to the journal.

This is an open-access article distributed under the terms and conditions of the Creative Commons Attribution license (http://creativecommons.org/licenses/by/4.0/). 